ISSN 1678-3921

Journal homepage: www.embrapa.br/pab

For manuscript submission and journal contents, access: www.scielo.br/pab
Jéssyca Dellinhares Lopes Martins ${ }^{(1)}(\mathrm{D}$, Rogério Peres Soratto ${ }^{(1 凶)}$ (iD and Adalton Mazetti Fernandes(2) (D)

(1) Universidade Estadual Paulista Júlio de Mesquita Filho, Faculdade de Ciências Agronômicas, Departamento de Produção Vegetal, Campus de Botucatu, Avenida Universitária, ํㅜ 3.780, Fazenda Experimental Lageado, CEP 18610-034 Botucatu, SP, Brazil.

E-mail: dellinhares@hotmail.com, rogerio.soratto@unesp.br

(2) Universidade Estadual Paulista Júlio de Mesquita Filho, Centro de Raízes e Amidos Tropicais, Campus de Botucatu, Avenida Universitária, № 3.780, Fazenda Experimental Lageado, CEP 18610-034 Botucatu, SP, Brazil.

E-mail: adalton.fernandes@unesp.br

$\bowtie$ Corresponding author

Received

November 7, 2019

Accepted

June 25, 2020

How to cite

MARTINS, J.D.L.; SORATTO, R.P.;

FERNANDES, A.M. Potato yield and

phosphorus nutrition using humic substances

in two soil textures. Pesquisa Agropecuária Brasileira, v.55, e01703, 2020. DOI: https://doi. org/10.1590/S1678-3921.pab2020.v55.01703.

\section{Potato yield and phosphorus nutrition using humic substances in two soil textures}

\begin{abstract}
The objective of this work was to evaluate the effect of humic substances (HS) and phosphorus fertilizer on the growth, P uptake, tuber yield, fertilizer P recovery (FPR), and applied P-use efficiency (APUE) of potato (Solanum tuberosum) cultivated in a sandy and in a clayey soils. In both soils, the experiment was carried out in a randomized complete block design, in a $4 \times 3$ factorial arrangement, with four replicates. The treatments consisted of four $\mathrm{P}$ rates $\left(0,100,200\right.$, and $\left.400 \mathrm{~kg} \mathrm{ha}^{-1} \mathrm{P}_{2} \mathrm{O}_{5}\right)$ and of three HS rates $\left(0,50\right.$, and $\left.300 \mathrm{~L} \mathrm{ha}^{-1}\right)$. Phosphate fertilization increased the $\mathrm{P}$ uptake and tuber yield of potato in both soils. Soil characteristics conditioned the effect of the addition of HS. In the sandy soil, with a lower content of organic matter (OM) than the clayey soil, the addition of HS increases the P uptake and FPR, besides providing a greater tuber yield and APUE, especially under the $\mathrm{P}$ absence or with the application of a reduced P rate. In the clayey soil, HS does not affect the response of potato to $P$ fertilization.
\end{abstract}

Index terms: Solanum tuberosum, humic acid, mineral nutrition, soil organic matter, soil texture.

\section{Produtividade e nutrição fosfatada da batateira com uso de substâncias húmicas em dois tipos de texturas de solos}

Resumo - O objetivo deste trabalho foi avaliar o efeito de substâncias húmicas (SH) e adubo fosfatado sobre o crescimento, a absorção de fósforo (P), a produtividade de tubérculos, a recuperação do $\mathrm{P}$ do fertilizante (RPF) e a eficiência de uso do P aplicado (EUPA) de batateira (Solanum tuberosum) cultivada em um solo arenoso e em um argiloso. Em ambos os solos, o experimento foi realizado em delineamento de blocos ao acaso, em arranjo fatorial $4 \times 3$, com quatro repetições. Os tratamentos consistiram de quatro doses de $\mathrm{P}\left(0,100,200\right.$ e $400 \mathrm{~kg} \mathrm{ha}^{-1}$ de $\left.\mathrm{P}_{2} \mathrm{O}_{5}\right)$ e de três de $\mathrm{SH}(0,50$ e $300 \mathrm{~L}$ ha ${ }^{-1}$ ). A adubação fosfatada aumentou a absorção de $\mathrm{P}$ e a produtividade de tubérculos da cultura da batateira em ambos os solos. As características do solo condicionaram o efeito da aplicação de SH. No solo arenoso, com menor conteúdo de matéria orgânica do que no solo argiloso, a aplicação de SH aumenta a absorção de $\mathrm{P}$ e a RPF, bem como proporciona maior produtividade de tubérculos e maior EUPA, especialmente na ausência de P ou em aplicação com dose reduzida de P. No solo argiloso, a aplicação de SH não afeta a resposta da cultura da batata à adubação fosfatada.

Termos para indexação: Solanum tuberosum, ácido húmico, nutrição mineral, matéria orgânica do solo, textura do solo. 


\section{Introduction}

Potato (Solanum tuberosum L.) cultivation is highly demanding for nutrients available in the soil because of its short cycle, high growth rate, and high yield per unit of area (Fernandes et al., 2011; Fleisher et al., 2013; Fernandes \& Soratto, 2016a). Phosphorus (P) ranks first among the macronutrients whose deficiencies are most limiting for potato yield in tropical soils (Luz et al., 2013; Fernandes \& Soratto, 2016a, 2016b). This occurs because the recovery of fertilizer $\mathrm{P}$ by plants is usually very low due to the high capacity of soils to adsorb/bond $\mathrm{P}$ to soil constituents, especially in acid clayey soils (Falcão \& Silva, 2004; Novais et al., 2007).

Potato plant takes up approximately $0.6 \mathrm{~kg} \mathrm{P}$ from the soil for each tonne of tubers produced, and about $78 \% \mathrm{P}$ is removed by the tubers (Fernandes et al., 2011). In soils with low $\mathrm{P}$ availability, potato shows reduced stem length, leaf size and number, and leaf area, compromising the plant dry matter (DM) production (Fleisher et al., 2013; Fernandes $\&$ Soratto, 2016b). The number, size, and yield of tubers are also significantly reduced (Fleisher et al., 2013; Luz et al., 2013; Fernandes \& Soratto, 2016a, 2016b). Therefore, high rates of $P$ fertilizer have been applied in potato cultivation, and the use efficiency of applied P is usually low (Luz et al., 2013; Fernandes \& Soratto, 2016a).

In order to improve the efficiency of P fertilizer, it is possible to use fertilizers containing humic substances (HS), or apply them directly to the soil (Seyedbagheri, 2010). HS are, in general, sources of humic and fulvic acids that reduce the $\mathrm{P}$ adsorption in soil colloids, increasing their availability and, consequently, their uptake by crops (Selim et al., 2009; Seyedbagheri, 2010). In addition, HS can improve the moisture retention in sandy soils (Selim et al., 2009). In plants, HS has an effect similar to that of auxin hormone, with improvements of the root system development (Canellas et al., 2002; Zandonadi et al., 2007) and activation of proton pump ATPases present in the cell membrane (Canellas et al., 2002; Mora et al., 2010), which results in an increased nutrient uptake (Eyheraguibel et al., 2008; Baldotto et al., 2009) and plant biomass production (AbuZinada \& Sekh-Eleid, 2015). Specifically for potato cultivation, the use of HS associated, or not, with mineral fertilizer has resulted in increased vegetative growth, plant height, leaf area, and DM production (Abu-Zinada \& Sekh-Eleid, 2015), increased wateruse efficiency, and specific gravity and starch content in tubers (Alenazi et al., 2016), and promoted the increase of potato tuber yield (Sanli et al., 2013; Alenazi et al., 2016).

The agricultural use of HS-based products has been growing. However, the effect of applying HS to soil has limitations, especially for the rate to be applied (Sanli et al., 2013; Abu-Zinada \& Sekh-Eleid, 2015), as well as for the amount of organic matter (OM) (Hartz \& Bottoms, 2010; Summerhays et al., 2015) and soil texture (Selim et al., 2009) to be used; nevertheless, the results are still contradictory (Seyedbagheri, 2010).

It is possible that the addition of HS to the soil increases the efficiency of phosphate fertilization, with higher P uptake by plants and a yield increase of potato tubers, depending on the soil texture.

The objective of this work was to evaluate the effect of HS and P fertilizer on the growth, P uptake, tuber yield, fertilizer P recovery (FPR), and applied P-use efficiency (APUE) of potato cultivated in a sandy and in a clayey soils.

\section{Materials and Methods}

Two field experiments were carried out during the 2015 fall-winter cropping season, in the state of São Paulo, Brazil, in two soil types: a sandy-textured Latossolo Vermelho distrófico (Typic Hapludox), and a clayey-textured Nitossolo Vermelho distroférrico (Typic Rodudalf), according to Santos et al. (2013). The sandy soil was in the municipality of São Manuel ( $22^{\circ} 46^{\prime} \mathrm{S}, 48^{\circ} 34^{\prime} \mathrm{W}$, at $740 \mathrm{~m}$ altitude), and the clayey one, in the municipality of Botucatu $\left(22^{\circ} 51^{\prime} \mathrm{S}\right.$, $48^{\circ} 26^{\prime} \mathrm{W}$, at $786 \mathrm{~m}$ altitude).

The predominant climate in the region is subtropical Cfa, according to the Köppen-Geiger's classification, characterized by dry season and hot summer. Rainfall and temperature were measured daily, during the experimental periods (Figure 1).

Before the potato planting, soil samples were collected at $0.0-0.20-\mathrm{m}$ soil depths. The sandy soil showed the following characteristics: $7 \mathrm{~g} \mathrm{dm}^{-3} \mathrm{OM}$; $5.4 \mathrm{pH}\left(\mathrm{CaCl}_{2}\right) ; 8 \mathrm{mg} \mathrm{dm}^{-3} \mathrm{P}_{\text {resin }} ; 0.8 \mathrm{mmol}_{\mathrm{c}} \mathrm{dm}^{-3} \mathrm{~K}, 13$ $\mathrm{mmol}_{\mathrm{c}} \mathrm{dm}^{-3} \mathrm{Ca}, 6 \mathrm{mmol}_{\mathrm{c}} \mathrm{dm}^{-3} \mathrm{Mg}$, and $14 \mathrm{mmol}_{\mathrm{c}} \mathrm{dm}^{-3}$ $\mathrm{H}+\mathrm{Al} ; 3,0.09,0.5,13,14$, and $0.8 \mathrm{mg} \mathrm{dm}^{-3} \mathrm{~B}, \mathrm{Cu}$, 
$\mathrm{Fe}, \mathrm{Mn}, \mathrm{Zn}$, and $\mathrm{SO}_{4}-\mathrm{S}$, respectively; base saturation (BS) of 59\%; and 874, 22, and $102 \mathrm{~g} \mathrm{~kg}^{-1}$ sand, silt, and clay, respectively. The clayey soil characteristics were as follows: $26 \mathrm{~g} \mathrm{dm}^{-3} \mathrm{OM} ; 5.1 \mathrm{pH}\left(\mathrm{CaCl}_{2}\right) ; 13 \mathrm{mg}$ $\mathrm{dm}^{-3} \mathrm{P}_{\text {resin }} ; 2.2 \mathrm{mmol}_{\mathrm{c}} \mathrm{dm}^{-3} \mathrm{~K}, 46 \mathrm{mmol}_{\mathrm{c}} \mathrm{dm}^{-3} \mathrm{Ca}, 22$ $\mathrm{mmol}_{\mathrm{c}} \mathrm{dm}^{-3} \mathrm{Mg}$, and $39 \mathrm{mmol}_{\mathrm{c}} \mathrm{dm}^{-3} \mathrm{H}+\mathrm{Al} ; 4 \mathrm{mg} \mathrm{dm}^{-3}$ $\mathrm{B}, 0.44 \mathrm{mg} \mathrm{dm}^{-3} \mathrm{Cu}, 4.3 \mathrm{mg} \mathrm{dm}^{-3} \mathrm{Fe}, 26 \mathrm{mg} \mathrm{dm}^{-3} \mathrm{Mn}, 8$ $\mathrm{mg} \mathrm{dm}^{-3} \mathrm{Zn}$, and $1.8 \mathrm{mg} \mathrm{dm}^{-3} \mathrm{SO}_{4}-\mathrm{S} ; 64 \% \mathrm{BS}$; and 280 $\mathrm{g} \mathrm{kg}^{-1}$ sand, $90 \mathrm{~g} \mathrm{~kg}^{-1}$ silt, and $630 \mathrm{~g} \mathrm{~kg}^{-1}$ clay.

The experiments were carried out in a randomized complete block design, with a $4 \times 3$ factorial arrangement consisted of four $\mathrm{P}$ rates $(0,100,200$, and $400 \mathrm{~kg} \mathrm{ha}^{-1} \mathrm{P}_{2} \mathrm{O}_{5}$ ) and three $\mathrm{HS}$ rates $[0,50$ (recommended), and $300 \mathrm{~L} \mathrm{ha}^{-1}$ ], in $4 \times 5 \mathrm{~m}$ plots, and four replicates. Each plot consisted of five 5-m-long rows, with $0.80 \mathrm{~m}$ row spacing. For the evaluations, the three central rows were considered, and $0.5 \mathrm{~m}$ was excluded at the end of each row.
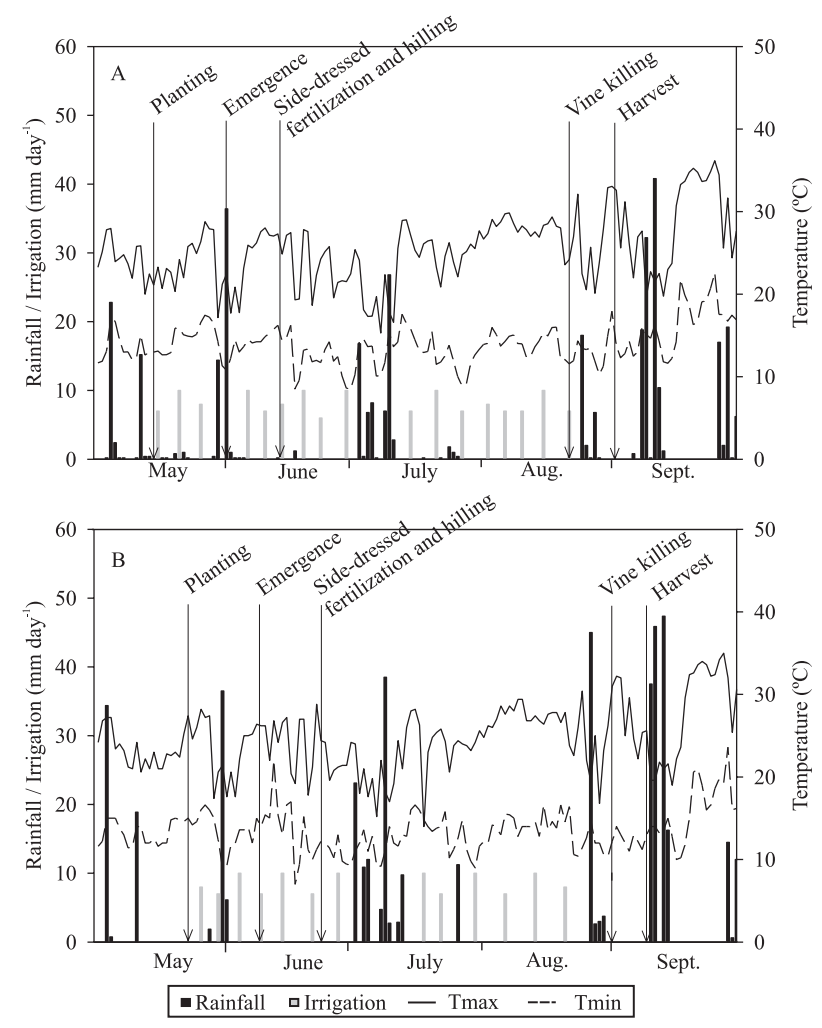

Figure 1. Daily rainfall, irrigation, and maximum and minimum air temperatures recorded from the May to September 2015, in the experimental areas with the sandy (A) and clayey (B) soils, in São Manuel and Botucatu, respectively, in São Paulo state, Brazil.
Soil tillage consisted of two heavy disk-harrowing operations, chiseling, and light harrowing, which occurred in the day before planting. Potatoes were planted on 14 and 22 May, 2015, in the sandy and clayey soil experiments, respectively. The furrows were mechanically opened using a furrower-planter. At planting, all plots received $80 \mathrm{~kg} \mathrm{ha}^{-1} \mathrm{~N}$ (urea, 44 $\% \mathrm{~N}$ ), $150 \mathrm{~kg} \mathrm{ha}^{-1} \mathrm{~K}_{2} \mathrm{O}$ (potassium chloride, $60 \%$ $\left.\mathrm{K}_{2} \mathrm{O}\right), 200 \mathrm{~kg} \mathrm{ha}^{-1}$ phosphogypsum $(22 \% \mathrm{Ca}$, and $17 \%$ $\mathrm{S}$ ), and $50 \mathrm{~kg} \mathrm{ha}^{-1}$ of fritted trace elements (FTE BR12 , containing $1.8 \% \mathrm{~B}, 0.8 \% \mathrm{Cu}, 2 \% \mathrm{Mn}, 9 \% \mathrm{Zn}, 3 \%$ $\mathrm{Fe}$, and $1 \% \mathrm{Mo}$ ). The phosphate fertilizer was also applied in the furrows according to the treatments, using triple superphosphate $\left(46 \% \mathrm{P}_{2} \mathrm{O}_{5}\right)$ as source. The fertilizers were manually applied and slightly incorporated into the furrows, using a hoe at 0.15 $\mathrm{m}$ average depth with the seed tubers $0.05 \mathrm{~m}$ above. Uncut seed tubers (type III, with diameters between 30 and $40 \mathrm{~mm}$ ) of the potato cultivar 'Agata' were hand-planted in furrows spaced at $0.35 \mathrm{~m}$. The HS treatments were applied with a handheld sprayer on the seed tubers deposited in the furrow. As a source of HS, the commercial product Humic HF (Agrolatino Soil Conditioners \& Special Fertilizers, Rincão, SP, Brazil) was used. It is characterized as an organomineral fertilizer, source of humic and fulvic acids, presenting in its chemical composition $15.45 \mathrm{~g} \mathrm{~L}^{-1}$ $\mathrm{N}, 15.45 \mathrm{~g} \mathrm{~L}^{-1} \mathrm{~K}_{2} \mathrm{O}, 30.9 \mathrm{~g} \mathrm{~L}^{-1}$ total organic carbon, and it is composed of potassium hydroxide, urea, peat, and water. The pesticides kasugamycin $\left(40 \mathrm{~g} \mathrm{ha}^{-1}\right)$ and thiamethoxam (60 $\left.\mathrm{g} \mathrm{ha}^{-1}\right)$ were subsequently applied. Finally, the furrows were covered manually.

Plants emerged 16 days after planting (DAP) in the sandy soil, and 17 DAP in the clayey soil. Sidedressing fertilization was applied 30 DAP to both experiments, and $80 \mathrm{~kg} \mathrm{ha}^{-1} \mathrm{~N}$ (ammonium sulphate, $20 \% \mathrm{~N}$ ) and $100 \mathrm{~kg} \mathrm{ha}^{-1} \mathrm{~K}_{2} \mathrm{O}$ (potassium chloride) were applied simultaneously with hilling immediately after sidedressing. Invasive plants were controlled by hand weeding when necessary. The preventive pest management was performed weekly from 34 DAP on, with the following insecticides and fungicides: acetamiprid (300 $\mathrm{g} \mathrm{ha}^{-1}$ a.i.), chlorphenapyr (300 $\mathrm{g} \mathrm{ha}^{-1}$ a.i.), abamectin (10 $\mathrm{g} \mathrm{ha}^{-1}$ a.i.), chlorpyrifos (530 $\mathrm{g} \mathrm{ha}^{-1}$ a.i.), kasugamycin (35 $\mathrm{g} \mathrm{ha}^{-1}$ a.i.), metiram (1500 $\mathrm{g} \mathrm{ha}^{-1}$ a.i.), mancozeb (1500 $\mathrm{g} \mathrm{ha}^{-1}$ a.i.), propamorcabe hydrochloride (100 $\mathrm{g} \mathrm{ha}^{-1}$ a.i.), and copper oxychloride (360 $\mathrm{g} \mathrm{ha}^{-1}$ a.i.). The experiments were irrigated with 
a conventional sprinkler system, according to water requirements of the crop.

The third-expanded leaf from the apex was collected from 15 randomly selected plants per plot, at $50 \mathrm{DAP}$ and $45 \mathrm{DAP}$, in the experiments with sandy and clayey soil, respectively. The leaves were rinsed with deionized water, dried in a forced-air oven, at $65^{\circ} \mathrm{C}$ for 72 hours, then ground and used for the analysis of $\mathrm{P}$ and $\mathrm{Zn}$ concentrations (Malavolta et al., 1997). Five plants at the tuber maturation stage were collected from the analysis area of each plot one day before vine killing. These plants were divided into tubers and shoots (leaves, stems, and stolons), separately rinsed with deionized water, and dried in a forced-air oven, at $65^{\circ} \mathrm{C}$ for 96 hours. Dry plant parts were weighed, and the DM accumulation in the tubers and shoots was calculated. The dry plant tissues were separately ground and used for the analysis of $\mathrm{P}$ concentration (Malavolta et al., 1997). Total P uptake was calculated as the sum of the amounts of $\mathrm{P}$ that accumulated in the tubers and shoots of the plant before the vine killing. The amounts of $\mathrm{P}$ accumulated in the tubers and shoots were calculated by multiplication of $\mathrm{P}$ concentration of each plant part by the amount of accumulated DM.

Potato vine killing was performed with the herbicide paraquat (400 $\mathrm{g} \mathrm{ha}^{-1}$ a.i.) at 96 and 98 DAP, in sandy and clayey soils, respectively. The potatoes were harvested at 108 and 102 DAP in the experiments in sandy and clayey soils, respectively. Tubers from two 1.5 -m-long rows (ten plants), in the useful area of each plot, were excavated with a spade and manually collected. The tubers were graded to determine the total yield and the yield of tubers $>45 \mathrm{~mm}$. After they had been sorted, the tubers were counted and weighed to determine the number of tubers per plant, tuber mean weight, and tuber yield. The percentage of tubers of $>45 \mathrm{~mm}$ was expressed as a percentage of tubers in relation to the total tuber yield.

The percent of fertilizer $\mathrm{P}$ recovery (FPR) was calculated by the traditional method, with the following equation presented by Chien et al. (2012): FPR $(\%)=\{[$ P uptake in a treatment (with $\mathrm{P}$ and/or HS) - P uptake in the absolute control (no P or HS)] $/$ amount of $\mathrm{P}$ fertilizer applied $\} \times 100$. The APUE for tuber yield in a treatment was determined by the division of the difference between the tuber yield of a treatment (with $\mathrm{P}$ and/or HS) and the tuber yield of the absolute control (no P or HS) by the $\mathrm{P}_{2} \mathrm{O}_{5}$ fertilization rate.

The data from each experiment were separately subjected to the analysis of variance using the Sisvar statistical software package (Universidade Federal de Lavras, Lavras, MG). The means of the HS treatments were compared by Tukey's test, at 5\% probability. The effects of the $\mathrm{P}$ fertilizer rates were evaluated by the regression analysis and plotted using SigmaPlot 10.0 software (Systat Software, Inc., San Jose, CA).

\section{Results and Discussion}

Leaf $\mathrm{P}$ concentration in potato plants, cultivated in both soils, was influenced only by $\mathrm{P}$ rates (Figure 2). Phosphate fertilization increased the leaf $\mathrm{P}$ concentration up to the estimated rate of $392 \mathrm{~kg} \mathrm{ha}^{-1}$ $\mathrm{P}_{2} \mathrm{O}_{5}$, in the sandy soil, and up to the highest rate used (400 kg ha-1 $\left.\mathrm{P}_{2} \mathrm{O}_{5}\right)$ in the clayey soil. However, only in the absence of $\mathrm{P}$ fertilization, in the sandy soil, the leaf $\mathrm{P}$ concentration was below the range considered suitable for potato (from 2.5 to $5.0 \mathrm{~g} \mathrm{~kg}^{-1}$ ) by Lorenzi et al. (1997).

In the sandy soil, leaf $\mathrm{Zn}$ concentration was affected by the $\mathrm{HS} \times \mathrm{P}$ interaction (Figure 2). In the absence of HS, and with a rate of $50 \mathrm{~L} \mathrm{ha}^{-1} \mathrm{HS}$, the concentration of $\mathrm{Zn}$ increased up to the highest $\mathrm{P}$ fertilizer rate. At the highest $\mathrm{P}$ rate, the use of 300 $\mathrm{L} \mathrm{ha}^{-1} \mathrm{HS}$ promoted a lower leaf $\mathrm{Zn}$ concentration than other HS treatments. In the clayey soil, there was no effect of HS nor of P fertilization on the leaf $\mathrm{Zn}$ concentration that presented an average value of $30 \mathrm{mg} \mathrm{kg}^{-1}$. In all treatments and both soils, leaf $\mathrm{Zn}$ concentrations were within or above the range considered appropriate for potato (from 20 to $60 \mathrm{mg}$ $\mathrm{kg}^{-1}$ ) (Lorenzi et al., 1997). Excessive P fertilizer may induce $\mathrm{Zn}$ deficiency under low or marginal available $\mathrm{Zn}$ condition, by decreasing soil $\mathrm{Zn}$ diffusion and interfering with the uptake, translocation, and use of Zn by plants (Fageria, 2001); however, this fact was not observed in the present work.

In the sandy soil, DM accumulated in the shoots, tubers, and whole plant, before vine killing, were influenced by the $\mathrm{HS} \times \mathrm{P}$ interaction (Figure 2). With the lowest $\mathrm{P}$ rates $\left(0\right.$ and $\left.100 \mathrm{~kg} \mathrm{ha}^{-1} \mathrm{P}_{2} \mathrm{O}_{5}\right)$, HS (50 or $300 \mathrm{~L} \mathrm{ha}^{-1} \mathrm{HS}$ ) increased the amounts of DM accumulated in shoots. In the absence of

Pesq. agropec. bras., Brasília, v.55, e01703, 2020

DOI: 10.1590/S1678-3921.pab2020.v55.01703 

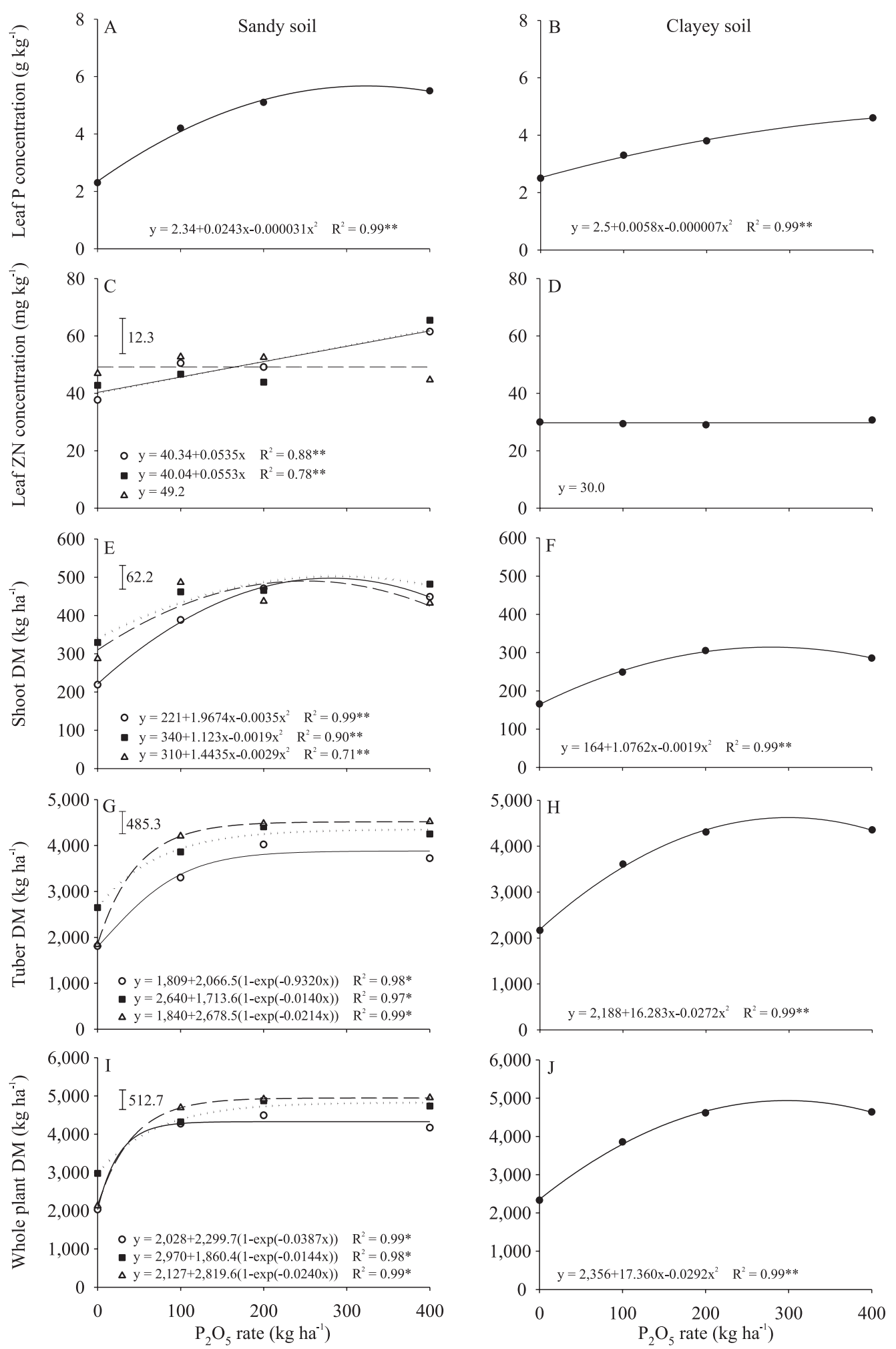

$\circ 0 \mathrm{~L} \mathrm{ha}^{-1} \cdot 50 \mathrm{~L} \mathrm{ha}^{-1} \quad \Delta 300 \mathrm{~L} \mathrm{ha}^{-1} \quad$ mean of three HS rates

Figure 2. Leaf $\mathrm{P}(\mathrm{A}$ and $\mathrm{B})$ and leaf $\mathrm{Zn}(\mathrm{C}$ and $\mathrm{D})$ concentrations, and shoot (E and F), tuber (G and $\mathrm{H})$, and whole plant (I and $\mathrm{J})$ dry matter (DM) of the potato cultivation affected by the use of humic substance (HS) and phosphate fertilizer rates, when cultivated in sandy (A, C, E, G, and I) and clayey (B, D, F, H, and J) soils. Vertical bars indicate the least significant difference to separate HS rates in a same phosphate fertilizer rate, by the Tukey's test, at 5\% probability. ${ }^{*}, * *$ Significant at $5 \%$ and $1 \%$, respectively. 
the $\mathrm{P}$ fertilization, the rates of $50 \mathrm{~L} \mathrm{ha}^{-1} \mathrm{HS}$ also increased by approximately $1,000 \mathrm{~kg} \mathrm{ha}^{-1}$ the amounts of DM accumulated in tubers and whole plant, in comparison to the other HS treatments. The increase of tuber DM was also substantial with the a of the highest HS rate associated with $100 \mathrm{~kg} \mathrm{ha}^{-1}$ $\mathrm{P}_{2} \mathrm{O}_{5}$, and at the highest $\mathrm{P}$ rate, regardless of the HS rate. The increase of the vegetative growth, plant height, leaf area, and DM production of potato plant was also observed with the addition of HS rates associated with NPK fertilizer, in the experiment of Abu-Zinada \& Sekh-Eleid (2015). The action of HS on DM production by plants is due to a sum of effects on plant growth and development, caused by lateral root development, which is controlled by auxin (Canellas et al., 2002; Zandonadi et al., 2007), resulting in increased nutrient uptake (Eyheraguibel et al., 2008; Baldotto et al., 2009; Mora et al., 2010), increase of chlorophyll and carotenoid biosynthesis, and improvement of photosynthetic characteristics of plants (Baldotto et al., 2009). In the sandy soil, regardless of $\mathrm{HS}, \mathrm{P}$ fertilization increased the amounts of DM accumulated in the plant parts only for rates between 100 and $200 \mathrm{~kg} \mathrm{ha}^{-1} \mathrm{P}_{2} \mathrm{O}_{5}$.

In the clayey soil, there was an isolated effect of $P$ rate on DM accumulation in the shoots, tubers, and the whole plant (Figure 2). The accumulated DM amounts (shoots, tubers, and whole plant) increased up to approximately the estimated rate of $300 \mathrm{~kg} \mathrm{ha}^{-1} \mathrm{P}_{2} \mathrm{O}_{5}$, which can be explained by the role that $\mathrm{P}$ plays in several processes in the plant, such as photosynthesis, storage, and transfer of energy (Malavolta et al., 1997). P-deficient potato plants show low DM accumulation because of their limited leaf area and photosynthesis (Fleisher et al., 2013).

Irrespectively of the HS treatments, $\mathrm{P}$ fertilizer rates increased the $\mathrm{P}$ concentration, both in the shoots and tubers of the potato plants in both soils (Figure 3). It should be noted that in the sandy soil, the effect of $P$ fertilizer rates on the increase of the $P$ concentration in the tubers was greater than in the clayey soil. In the sandy soil, the amount of $\mathrm{P}$ taken up by the potato crop was influenced by the HS $\times \mathrm{P}$ interaction. Especially at the highest $P$ rates $(200$ and $400 \mathrm{~kg} \mathrm{ha}^{-1} \mathrm{P}_{2} \mathrm{O}_{5}$ ), both HS rates outperformed the treatment without HS. Regardless of HS addition, $P$ uptake was increased up to estimated rates of approximately $340 \mathrm{~kg} \mathrm{ha}^{-1} \mathrm{P}_{2} \mathrm{O}_{5}$, reflecting on the effects observed on the DM accumulation, as well as on $\mathrm{P}$ concentration in plant tissues (Figures 2 and 3).

In the clayey soil, there was only an isolated effect of the P fertilization on P uptake by potato, with an increase up to the highest $\mathrm{P}$ rate, however, the effect was smaller than that on the sandy soil (Figure 3). Increased $\mathrm{P}$ uptake in response to $\mathrm{P}$ fertilizer supply is expected, as the concentration of this nutrient in shoots and tubers was also linearly increased. However, the high rates of $\mathrm{P}$ fertilizer may lead to unnecessary uptake of $P$, when high rates of the nutrient are applied, since increases of $P$ concentrations in plant tissues were observed up to higher rates of $\mathrm{P}$ fertilizer than those that provided increases in DM accumulation (Malavolta et al., 1997; Fernandes \& Soratto, 2016b).

The FPR was also affected by the HS $\times \mathrm{P}$ interaction in the sandy soil (Figure 4). In the presence of the highest $\mathrm{P}$ rates $\left(200\right.$ and $400 \mathrm{~kg} \mathrm{ha}^{-1}$ $\mathrm{P}_{2} \mathrm{O}_{5}$ ), the use of HS promoted FPR higher than the treatment without HS. The HS can reduce the $\mathrm{P}$ adsorption on soil colloids (Selim et al., 2009; Seyedbagheri, 2010), as well it can increase root growth (Canellas et al., 2002; Zandonadi et al., 2007), and activate the proton-pumping ATPases in the cell membrane (Canellas et al., 2002; Mora et al., 2010), which results in an increased nutrient uptake (Eyheraguibel et al., 2008; Baldotto et al., 2009). However, in the clayey soil, no effects of HS were observed. In general, the values of FPR were higher in the sandy than in the clayey soil because the initial $\mathrm{P}_{\text {resin }}$ concentration in the clayey soil was higher, and the P-adsorption capacity and energy showed positive correlations with the soil-clay content (Falcão \& Silva, 2004; Novais et al., 2007). In the sandy soil, the available $\mathrm{P}$ concentration will remain higher than in the clayey soil, and thus potato plants can uptake more P (Martins et al., 2018).

In the sandy soil, the number of tubers per plant, tuber mean weight, total tuber yield, proportion of tubers with $>45 \mathrm{~mm}$ diameter, and APUE were affected by the $\mathrm{HS} \times \mathrm{P}$ interaction (Figures 4 and 5). In the absence of $\mathrm{P}$ fertilization, the rate $50 \mathrm{~L} \mathrm{ha}^{-1}$ HS increased the number of tubers per plant, tuber mean weight, total tuber yield, and yield of $>45 \mathrm{~mm}$ tubers, in comparison to the absence of HS. The rate $50 \mathrm{~L} \mathrm{ha}^{-1} \mathrm{HS}$ also increased APUE of the potato

Pesq. agropec. bras., Brasília, v.55, e01703, 2020

DOI: 10.1590/S1678-3921.pab2020.v55.01703 
cultivation in the presence of $100 \mathrm{~kg} \mathrm{ha}^{-1} \mathrm{P}$. However, the highest $\mathrm{P}$ fertilizer rate, associated with the
$300 \mathrm{~L} \mathrm{ha}^{-1} \mathrm{HS}$, promoted a number of tubers per plant, and tuber yield smaller than the treatment with
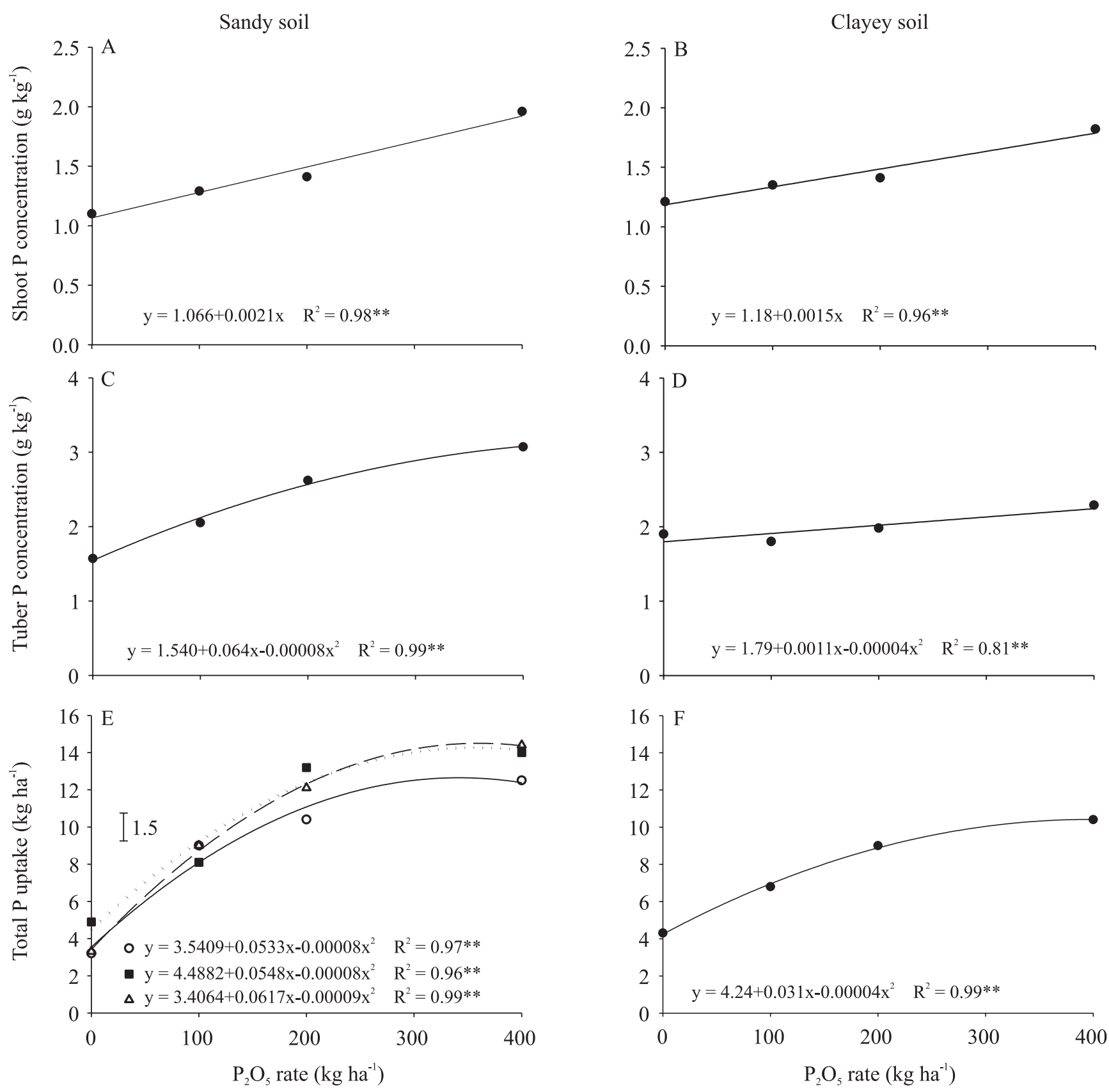

$$
\circ 0 \mathrm{~L} \mathrm{ha}^{-1} \quad 50 \mathrm{~L} \mathrm{ha}^{-1} \quad \Delta 300 \mathrm{~L} \mathrm{ha}^{-1} \quad \bullet \text { mean of three HS rates }
$$

Figure 3. Concentration of $\mathrm{P}$ in shoots $(\mathrm{A}$ and $\mathrm{B})$ and tubers $(\mathrm{C}$ and $\mathrm{D})$, and total $\mathrm{P}$ uptake $(\mathrm{E}$ and $\mathrm{F})$ of the potato crop affected by the use of humic substance (HS) and phosphate fertilizer rates, when cultivated in sandy (A, C, and E) and clayey (B, D, and F) soils. Vertical bars indicate the least significant difference to separate HS rates in a same phosphate fertilizer rate, by the Tukey's test, at $5 \%$ probability. ${ }^{*}{ }^{* *}$ Significant at $5 \%$ and $1 \%$, respectively. 
$50 \mathrm{~L} \mathrm{ha}^{-1} \mathrm{HS}$. In the absence of HS, the P fertilization increased the tuber yield more significantly than in treatments with HS and up to the highest $P$ rate studied. In the clayey soil, there was only an effect of $P$ rates increasing the number of tubers per plant and tuber mean weight, with an increase of the total tuber yield up to an estimated rate of $337 \mathrm{~kg} \mathrm{ha}^{-1}$ $\mathrm{P}_{2} \mathrm{O}_{5}$. However, the APUE decreased because of the applied $\mathrm{P}$ rates. The higher effects of HS in the sandy soil than that in the clayey soil may be related to improvements of water retention and nutrient maintenance in sandy soils (Selim et al., 2009). In addition, the effect of HS is intensified in soils with low OM content (Summerhays et al., 2015), like the sandy soil of the present study (Figures 2, 3, 4, and 5) that showed $7 \mathrm{~g} \mathrm{dm}^{-3} \mathrm{OM}$, which is much lower than that of the clayey soil $\left(26 \mathrm{~g} \mathrm{dm}^{-3} \mathrm{OM}\right)$.
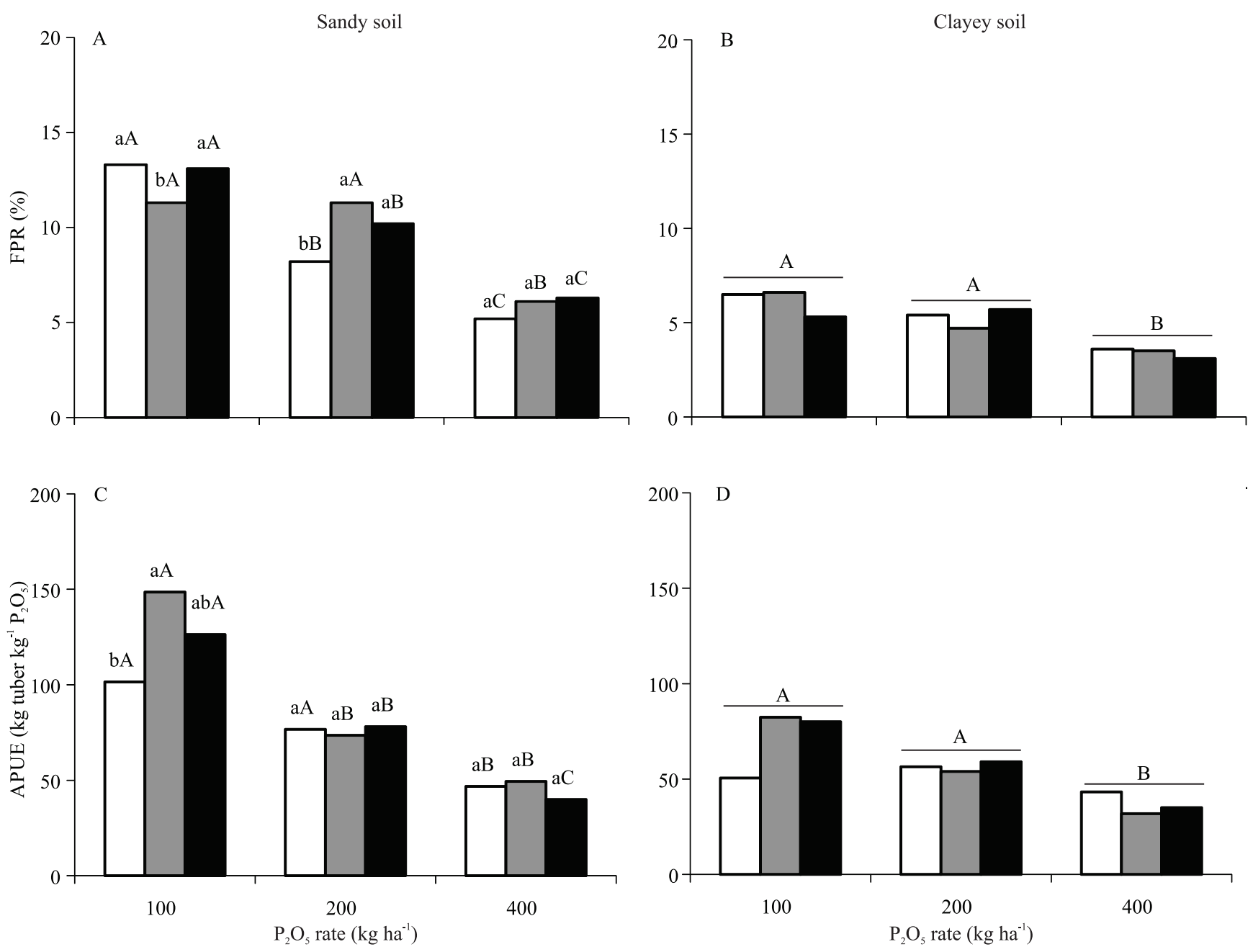

0 $0 \mathrm{Lha}^{-1}$ 口 $50 \mathrm{~L} \mathrm{ha}^{-1} \square 300 \mathrm{Lha}^{-1}$

Figure 4. Fertilizer P recovery (FPR, A and B) and applied P-use efficiency (APUE, C and D) of the potato crop affected by the use of humic substance (HS) and phosphate fertilizer rates, when cultivated in sandy (A and C) and clayey (B and D) soils. HS rates are: $0 \mathrm{~L} \mathrm{ha}^{-1} ; 50 \mathrm{~L} \mathrm{ha}^{-1} ; 300 \mathrm{~L} \mathrm{ha}^{-1}$. Different lowercase letters indicate a significant difference among HS rates, whereas different uppercase letters indicate a significant difference among phosphate fertilizer rates, by the Tukey's test, at $5 \%$ probability. 

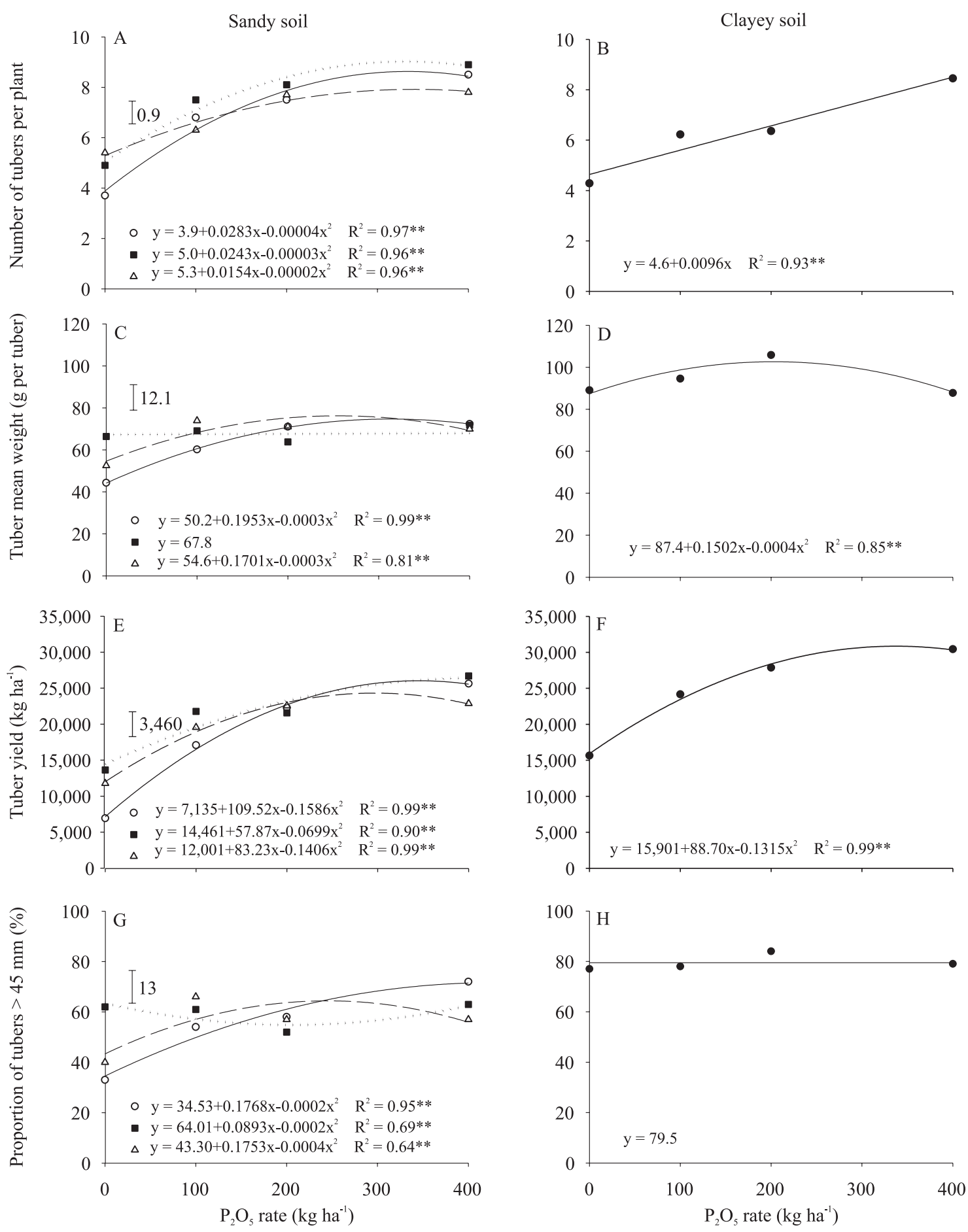

$$
\circ 0 \mathrm{~L} \mathrm{ha}^{-1} \quad 50 \mathrm{~L} \mathrm{ha}^{-1} \quad \Delta 300 \mathrm{~L} \mathrm{ha}^{-1} \quad \bullet \text { mean of three HS rates }
$$

Figure 5. Number of tubers per plant (A and $B)$, tuber mean weight (C and $D)$, total tuber yield ( $E$ and $F$ ), and proportion of tubers with a diameter larger than $45 \mathrm{~mm}(\mathrm{G}$ and $\mathrm{H})$ of the potato crop affected by the use of humic substance (HS) and phosphate fertilizer rates, when cultivated in sandy (A, C, E, and G) and clayey (B, D, F, and H) soils. HS rate: $0 \mathrm{~L} \mathrm{ha}^{-1}, 50$ $\mathrm{L} \mathrm{ha}^{-1}, 300 \mathrm{~L} \mathrm{ha}^{-1}$; and mean of three HS rates. Vertical bars indicate the least significant difference to separate HS rates in a same phosphate fertilizer rate, by the Tukey's test, at $5 \%$ probability. *, **Significant at $5 \%$ and $1 \%$, respectively. 


\section{Conclusions}

1. The use of humic substances in the potato cultivation in sandy soil increases the $\mathrm{P}$ uptake and the fertilizer $\mathrm{P}$ recovery, as well as it provides a higher number of tubers per plant, total tuber yield, yield of larger tubers, and applied P-use efficiency under the $\mathrm{P}$ absence, or application of reduced $\mathrm{P}$ fertilizer rate.

2. The use of humic substances does not affect the response of potato to the $\mathrm{P}$ fertilization in clayey soil.

3. The phosphate fertilization increases the $P$ uptake and tuber yield of potato cultivation in both soil textures.

\section{Acknowledgments}

To Coordenação de Aperfeiçoamento de Pessoal de Nível Superior (Capes), for providing a scholarship to the first author; and to Conselho Nacional de Desenvolvimento Científico e Tecnológico (CNPq), for granting an award for excellence in research to the second and third authors.

\section{References}

ABU-ZINADA, I.A.; SEKH-ELEID, K.S. Humic acid to decrease fertilization rate on potato (Solanum tuberosum L.). American Journal of Agriculture and Forestry, v.3, p.234-238, 2015. DOI: https://doi.org/10.11648/j.ajaf.20150305.20.

ALENAZI, M.; WAHB-ALLAH, M.A.; ABDEL-RAZZAK, H.S.; IBRAHIM, A.A.; ALSADON, A. Water regimes and humic acid application influences potato growth, yield, tuber quality and water use efficiency. American Journal of Potato Research, v.93, p.463-473, 2016. DOI: https://doi.org/10.1007/s12230-0169523-7.

BALDOTTO, L.E.B.; BALDOTTO, M.A.; GIRO, V.B.; CANELLAS, L.P.; OLIVARES, F.L.; BRESSAN-SMITH, B. Desempenho do abacaxizeiro 'Vitória' em resposta à aplicação de ácidos húmicos durante a aclimatação. Revista Brasileira de Ciência do Solo, v.33, p.979-990, 2009. DOI: https://doi.org/10.1590/S0100-06832009000400022.

CANELLAS, L.P.; OLIVARES, F.L.; OKOROKOVAFAÇANHA, A.L.; FAÇANHA, A.R. Humic acids isolated from earthworm compost enhance root elongation, lateral root emergence, and plasma membrane $\mathrm{H}^{+}$-ATPase activity in maize roots. Plant Physiology, v.130, p.1951-1957, 2002. DOI: https://doi.org/10.1104/pp.007088.

CHIEN, S.H.; SIKORA, F.J.; GILKES, R.J.; MCLAUGHLIN, M.J. Comparing of the difference and balance methods to calculate percent recovery of fertilizer phosphorus applied to soils: a critical discussion. Nutrient Cycling in Agroecosystems, v.92, p.1-8, 2012. DOI: https://doi.org/10.1007/s10705-011-9467-8.
EYHERAGUIBEL, B.; SILVESTRE, J.; MORARD, P. Effects of humic substances derived from organic waste enhancement on the growth and mineral nutrition of maize. Bioresource Technology, v.99, p.4206-4212, 2008. DOI: https://doi.org/10.1016/j. biortech.2007.08.082.

FAGERIA, V.D. Nutrient interactions in crop plants. Journal of Plant Nutrition, v.24, p.1269-1290, 2001. DOI: https://doi.org/10.1081/PLN-100106981.

FALCÃO, N.P. de S.; SILVA, J.R.A. da. Características de adsorção de fósforo em alguns solos da Amazônia Central. Acta Amazonica, v.34, p.337-342, 2004. DOI: https://doi.org/10.1590/ S0044-59672004000300001.

FERNANDES, A.M.; SORATTO, R.P. Phosphorus fertilizer rate for fresh market potato cultivars grown in tropical soil with low phosphorus availability. Americam Journal of Potato Research, v.93, p.404-414, 2016a. DOI: https://doi.org/10.1007/s12230-0169515-7.

FERNANDES, A.M.; SORATTO, R.P. Response of potato cultivars to phosphate fertilization in tropical soils with different phosphorus availabilities. Potato Research, v.59, p.259-278, 2016b. DOI: https://doi.org/10.1007/s11540-016-9330-z.

FERNANDES, A.M.; SORATTO, R.P.; SILVA, B.L. Extração e exportação de nutrientes em cultivares de batata: I - Macronutrientes. Revista Brasileira de Ciência do Solo, v.35, p.2039-2056, 2011. DOI: https://doi.org/10.1590/S010006832011000600020 .

FLEISHER, D.H.; WANG, Q.; TIMLIN, D.J.; CHUN, J.-A.; REDDY, V.R. Effects of carbon dioxide and phosphorus supply on potato dry matter allocation and canopy morphology. Journal of Plant Nutrition, v.36, p.566-586, 2013. DOI: https://doi.org/10. 1080/01904167.2012.751998.

HARTZ, T.K.; BOTTOMS, T.G. Humic substances generally ineffective in improving vegetable crop nutrient uptake or productivity. HortScience, v.45, p.906-910, 2010. DOI: https://doi.org/10.21273/HORTSCI.45.6.906.

LORENZI, J.O.; MONTEIRO, D.A.; MIRANDA FILHO, H.S.; RAIJ, B. van. Raízes e tubérculos. In: RAIJ, B. van; CANTARELLA, H.; QUAGGIO, J.A.; FURLANI, A.M.C. (Ed.). Recomendações de adubação e calagem para o Estado de São Paulo. 2.ed. rev. Campinas: IAC, 1997. p.221-229. (IAC. Boletim Técnico, 100).

LUZ, J.M.Q.; QUEIROZ, A.A.; BORGES, M.; OLIVEIRA, R.C.; LEITE, S.S.; CARDOSO, R.R. Influence of phosphate fertilization on phosphorus levels in foliage and tuber yield of the potato cv. Ágata. Semina: Ciências Agrárias, v.34, p.649-656, 2013. DOI: https://doi.org/10.5433/1679-0359.2013v34n2p649.

MALAVOLTA, E.; VITTI, G.C.; OLIVEIRA, S.A. de. Avaliação do estado nutricional das plantas: princípios e aplicações. 2.ed. Piracicaba: Associação Brasileira para Pesquisa da Potassa e do Fosfato, 1997. 319p.

MARTINS，J.D.L.; SORATTO, R.P.; FERNANDES， A.M.; DIAS, P.H.M. Phosphorus fertilization and soil texture affect potato yield. Revista Caatinga, v.31, p.541-550, 2018. DOI: https://doi.org/10.1590/1983-21252018v31n302rc.

MORA, V.; BACAICOA, E.; ZAMARREÑO, A.-M.; AGUIRRE, E.; GARNICA, M.; FUENTES, M.; GARCÍA-MINA, J.-M. 
Action of humic acid on promotion of cucumber shoot growth involves nitrate-related changes associated with the root-to-shoot distribution of cytokinins, polyamines and mineral nutrients. Journal of Plant Physiology, v.167, p.633-642, 2010. DOI: https://doi.org/10.1016/j.jplph.2009.11.018.

NOVAIS, R.F.; SMYTH, T.J.; NUNES, F.N. Fósforo. In: NOVAIS, R.F.; ALVAREZ V., V.H.; BARROS, N.F. de; FONTES, R.L.F.; CANTARUTTI, R.B.; NEVES, J.C.L. (Ed.). Fertilidade do solo. Viçosa: Sociedade Brasileira de Ciência do Solo, 2007. p.471-550.

SANLI, A.; KARADOGAN, T.; TONGUC, M. Effects of leonardite applications on yield and some quality parameters of potatoes (Solanum tuberosum L.). Turkish Journal of Field Crops, v.18, p.20-26, 2013.

SANTOS, H.G. dos; JACOMINE, P.K.T.; ANJOS, L.H.C. dos; OLIVEIRA, V.Á. de; LUMBRERAS, J.F.; COELHO, M.R.; ALMEIDA, J.A de; CUNHA, T.J.F.; OLIVEIRA, J.B. de. Sistema brasileiro de classificação de solos. 3.ed. rev. e ampl. Brasília: Embrapa, 2013. 353p.
SELIM, E.M.; EL-NEKLAWY, A.S.; EL-ASHRY, S.M. Beneficial effects of humic substances fertigation on soil fertility to potato grown on sandy soil. Australian Journal of Basic and Applied Science, v.3, p.4351-4358, 2009.

SEYEDBAGHERI, M.-M. Influence of humic products on soil health and potato production. Potato Research, v.53, p.341-349, 2010. DOI: https://doi.org/10.1007/s11540-010-9177-7.

SUMMERHAYS, J.S.; HOPKINS, B.G.; JOLLEY, V.D.; HILL, M.W.; RANSON, C.J.; BROWN, T.R. Enhanced phosphorus fertilizer (Carbond $\mathrm{P}^{\circledR}$ ) supplied to maize in moderate and high organic matter soils. Journal of Plant Nutrition, v.38, p.13591371, 2015. DOI: https://doi.org/10.1080/01904167.2014.973039.

ZANDONADI, D.B.; CANELLAS, L.P.; FAÇANHA, A.R. Indolacetic and humic acids induce lateral root development through a concerted plasmalemma and tonoplast $\mathrm{H}^{+}$ pumps activation. Planta, v.225, p.1583-1595, 2007. DOI: https://doi.org/10.1007/s00425-006-0454-2. 